\title{
Gender and the Politics of Power/ Powerlessness in John Nkemngong Nkengasong's Ancestral Earth
}

\author{
Florence Mbobu Ngie \\ Catholic University of Cameroon (CATUC) \\ Bamenda
}

\begin{abstract}
Absract
The Eurocentric historian, G.W. Hegel's assertion that Africa has no history, is underdeveloped, still involved in the conditions of mere nature and presented only as the threshold of world history is quite biased and racist inclined. Africa has a well organized culture and history that existed long before the coming of the Europeans. It is now common knowledge and a historical fact that Africa is the cradle of humanity and civilization, so Africa's history does not begin with her contact with the west as Hegel purports. Africa's underdevelopment is rated using Eurocentric standards. Moreover, the west is still to blame for Africa's under-development because they initiated corruption in Africa and has exploited Africa's rich natural and human resources for their benefits. The chosen topic: "Gender and the politics of power/ powerlessness" or gender politics, which refers to the way men and women compete for power, can be duly investigated within the backdrop of African history. African women just like their male counterparts understand their natural roles and act accordingly as read in two plays by John Nkemngong Nkengasong namely, Ancestral Earth. Gender issues raised in these plays are part and parcel of African history so Hegel's claim is either baseless or based on restrictive canonicity. Nkengasong's, as well as his contemporaries' works could be read as alternatives, critiquing or resistance to oppressive canons that lead to newfound tenable canons. The feminist theory will be the hub among others used to discuss the chosen topic and the selected play.
\end{abstract}

Keywords: Gender, politics, power.

\section{Introduction}

\section{Theoretical Foundation Of The Feminist Theory}

The feminist theory is relevant in reading and criticizing the play under study because it is not only a historical fact but a revolutionary movement around the globe. It is concerned both with the representation of women in literature and with the changing of women's position in the society by rendering them free from oppressive restrains. The feminist movement emanates from previous centuries' struggles by women to win equal rights with their male counterparts. The women's suffrage movement is linked with other social reforms such as the abolition of slavery, temperance and the extension of education. All this has to do with protest, self reassertion and assuming the true identity of a woman including the African woman. A thorough reading of the characters, especially females in Ancestral Earth led by Mafua and M'meka among others, could conveniently facilitate a critical analysis using this theory.

By the 1830s and 1840s women such as Palina Wright Davis and Lucnetice Matt, spoke out for women's rights at the "Seneca Falls Convention". Their ideas influenced writings, such as Mary Wallane Craft's A Valediction of the Rights of Women (1972), which articulates the case of women. In like manner, the women in Ancestral Earth by Nkengasong express their worries to the King and this leads to a solution to famine and destruction of the environment in their village. By so doing, these women are categorically protesting against suppression of speech and asking the African woman to change her former attitude of dying in silence. This suppression of speech experienced by African women is part of the patriarchal set up. In Betrothal without Libation, by Bole Butake, Bobe Ngong's first wife, Nandoh Bih, confirms this male domination in the African setting. When summoned, she stands until the husband asks her to sit as custom demands and says like the other women; she is there merely to take orders from the men and not to participate in decision making for the men do not involve them (38). This woman's words expose the identity of traditional African women thereby protesting against the inferior position given them and advocating a redefinition of self by implication. Fundamentally, three divergent strains of feminist criticism have emerged since the early 1970s namely; French, American and British. While the British and American ideologies are centered on issues concerning women suffrage and education, the French feminists focus their arguments on feminity and the derogatory use of language visà-vis the women. Maria, a female character in A Man out of the Country, a play by Anthony Akerman, is verbally attacked by her boyfriend, Tristan. 
The latter accuses her cheating and says lots of nasty things concerning this in the presence of his friends and guests. For instance, he brutally tells Maria to take a bath and change her underwear after the supposed sexual act with her other boyfriend. The truth is that Maria did not actually sleep with anybody that day and this false accusation caused her to weep bitterly. In like manner, King Akeumbin in Ancestral Earth incorrectly accuses the women of laziness instead of the men. He further fails to notice his flaws that qualify him as an indifferent leader. This is a feminist concern for the women are accused and condemned for acts which they have not committed while the lazy men and incompetent chief Akeumbin go scout free. The men therefore need to rectify their attitude towards women or anticipate a revolt because 'when man (representing both sexes) is pushed to wall, he has to revolt' as asserted by an Algerian philosopher named Albert Camus Carmile in L'homme Revolte.

However, the three different groups of feminist criticisms mentioned above are gynocentric. This means that they are searching for terminology to rescue the feminine gender from being a synonym of inferiority. This predicament is part and parcel of a woman's history and a change is inevitable. Lady Backwash an English woman, in 1837: The Farmers' Revolt by Rick Salutin, however portrays a different image of a woman. She calls an Indian man a savage and threatens to fire the coach driver who is a man. She also threatens and orders Johnson, her compatriot to get out of the coach and assist in pulling it against his will. Here the woman oppresses the man against the backdrop that she is a western emancipated woman.

There are four basic practices currently pursued in feminism namely: gender studies, psychoanalytic feminism, Marxist feminism and minority feminist criticisms. However, the focus here will be on gender studies and Marxist feminism. As far as gender studies are concerned some feminist critics stress on gender difference while others argue that female difference is what has caused female oppression. Lori Anderson, Elizabeth Abel and Maggie Hum are advocates of this assertion. However, their diverse opinions lead to a conclusion that women tend to define their lives in terms of their men; go out to compete in a man's world thereby accepting men's values and definition of success. This acceptance clearly indicates that women can never have it all for men have never and would never have it all. This is part of women's history but a change is needed. They can realize this by practicing redefinition of self and protesting when oppressed. This implies that women have to indulge in healthy competition not necessarily based on norms set by men; they should be creative and stop depending on men as exemplified by the women in Ancestral Earth.

\section{The Politics of Power/Powerlessness in Ancestral Earth.}

In this play by John Nkemngong Nkengasong, the women of Allehtendurih village have many things to complain about to their king. They are led by two dynamic women called Mafua and M'meka and their king is called Akeumbin. These women ingeniously suggest that the king in particular and all the men in general should change their attitudes. The king, who inherits the right to control people and events, does not have the ability. A king is supposed to lead, guide, care for and protect his subjects. Unfortunately, Akeumbin fails to live up to this expectation because of egotism. The men who have similar roles are so lazy and dependent on their wives consequently, the women rise and fight for their rights. This is a traditional African village setting whose culture and history can be verified so, women's rights or human rights are not a western invention per se. African people, especially women, have always known their rights and fought for their implementation from inception. This is exactly what the powerful women in this play are preoccupied with.

Fundamentally, the children are sick and there are rampant deaths because of famine and lack of water to drink in Allehtendurih village, yet no one seems to care about this precarious condition. M'meka and Mafua are touched by this situation. They therefore discuss it in a protest tone as seen in the following lines:

M'meka: My own children are hungry; they are sick and pale like the spirit, my mother told me in a story, ferried wizards across the sky.

Mafua: The streams are sour, they are dry. We do not have water to drink; we can no longer fish the tadpoles and the crabs to pound fufu for our husbands.

M'meka: And yet, our king, man beyond man, and our husbands do not scratch a pimple on their skins even when the soil continues to mock at our endeavours ( 52-53).

These women are expressing the destitution that the villagers, especially the women and children, are going through. Unfortunately, neither the king nor their husbands care about the untold suffering. The women therefore use words here to protest. They also expose their worries in the process thereby subtly wishing that the men should change their lukewarm attitudes and take up their responsibilities. These two archetypes confirm the assertion that feminism is not a western invention. The difference lies in the kind of feminism. As Africans, their brand of feminism is liberal while American and Western feminists' criticism is Marxist, social and radical. Emblematic traditional African women have little or nothing to learn from the west in this domain because African women are born and raised following certain norms and duties. It is obvious that they are conscious of their roles and any violation of their rights. 
In corroboration, we ironically decipher from Mafua's utterance above that the women still care about their husbands' nourishment despite their care free and selfish attitudes. She is worried about what their spouses will eat since there are no tadpoles and crabs in the sour dry streams. The women are still modest and motherly, a clear indication that they are morally and psychologically more powerful than the men. They are not only conscious of their rights but also of their obligations as housewives. The ensuing dialogue further elucidates this claim:

Mafua: [...]M'meka [...] I harvested very few groundnuts and cocoyams last season. There wasn't anything to eat out of it[...]I sold them to buy seedlings again this season. But my husband took the money to start paying the bride price of his new wife.

M'meka: Ugh! These men! They don't feel how much we suffer to feed the home. Even when the soil frowns at us! My own husband! You will find him now in a matango house, drunk, with the little money he made from selling a deer he shot yesterday, the only animal he has shot after hunting for so many weeks. He didn't leave any anini in the house for children to eat (53).

It goes without saying that these powerful women were brought up in resilience. Their flexibility in dealing with their husbands is not powerlessness but being more powerful. Mafua understands that polygamy is a common practice in her culture thus her problem is not the new wife but her hard earned money that is used to pay her bride price. In fact, a rich or great man in traditional Africa is one who has many wives and children as Chinua Achebe confirms in Things Fall Apart. M'meka's husband leaves no franc in the house for food after the sale of a deer but the wife will still serve him food on return from his drinking jaunt. She is a caring woman who will perform her duty before complaining. M'meka further says that her husband shamelessly complains of hunger, beats her up and insults her mother. He christens his mother-in-law a bush woman from the Yano tribe that produces palm oil. It takes only spiritually powerful women to be kind and tolerant to such offensive men. Western feminists will term this marginalization and cannot put up with such husbands. Conversely, the African woman is more mature because she sees these biases but clearly understands that marriage is not a bed of roses. It is for better, for worse as the Christian religion also teaches. Ironically, many western couples cannot practice what their religion teaches. Traditional Africans know the value of the institution of marriage so they are not based on contracts despite all odds. That is why the women in this play work hard to consolidate their marriages.

On the other hand, the women are clearly craving for a revolution by sharing their worries. They are tormented both physically and psychologically by the men who want to display their superiority complex. The men need to refrain from these chauvinistic attitudes because the African woman, though submissive and caring, should not be misconstrued as being powerless. She will persistently fight back and conquer the supposedly powerful man as seen at the end of this play. According to African history and norms, these men have to be responsible husbands who work and care for their families instead of exploiting and oppressing their wives. Such men as those mentioned in this play are found in every African society especially in village settings but in conformity with the resistant women of Allehtendurih, Beri Mary Shey in a DEA dissertation titled: "Class Bigotry and Self-Definition in Selected Works of Samuel Selvon and Bessie Head" (2008), posits that

"The spirit of resistance is characterised by the determination to erase unbearable human conditions arising from greed, hatred, abrasiveness, selfish human ambitions and class distinction. Self-definition is expressed through speeches, protests, resistance and demonstrations. All the measures adopted by characters to redefine their positions are noticeable in the social, cultural, intellectual, artistic and political domains (82).

While the men are busy drinking and doing nothing useful, the women in a revolutionary act move to the palace to confront the king. The latter keeps them waiting for such a long time but these determined women are patient. They are prepared to stay on until the king comes out to meet them so that they can find a solution to their problems. M'meka reiterates that the king must tell them that day whether the Earth which aches their feet is the same Earth their mothers used to praise in song. She is addressing the king who has not yet come out to meet them. He is still in bed with his fiftieth wife, Afingong. The two women leading the revolution attest:

Mafua: [...] We shall wait here at the entrance into the palace, till the king wakes from his young bride.

M'meka: Fua Akeumbin! How he prizes Afingong! It is like he never knew a woman all his life, even though the palace is filled with women. Fifty in number! (55)

The king is uninterested in the plight of his subjects but he is so concerned about his last wife. He spends much time with her and spends a lot of money on her upkeep. This satire is brought out by the two women leaders accordingly:

Mafua: A man's appetite for women is like the appetite of the grave during a plague. Afingong is just taking her turn to feed the appetite of the king like others before her. She too will fade and the king will marry yet another wife. 
M'meka: But the king exaggerates with Afingong. See how much of the wealth of Allehtendurih is lavished on her bangles, necklaces, cowries [...]

Mafua: She is still young and her blood is warm. The tender cocoyam leaf never knows that it will soon grow old and wither (55).

M'meka and Mafua once more expose male greed and powerlessness in front of women. They are so weak and carried away when they encounter a young beautiful woman. A man can do anything within his powers to lure a woman to his bed especially for the first time. He can walk long distances, flatter her with all kinds of sweet names and gifts to get sexual satisfaction. However, this is short-lived for sooner or later the woman will be cast off like some used old rag and replaced by another thereby exposing men's weakness in sustaining a relationship. This is the fate that awaits Afingong, who is the king's present favourite. Nevertheless, she is cautioned by the two experienced elderly women, who use astute words to implore both partners to change their ways and reasoning.

M'meka moves on to suggest a revolutionary action. She says they should move into the palace, into the king's room if possible, and put pressure on him to listen to them. Mafua conversely, rejects this proposal on grounds of an African value which is respect for elders and royalty. She reminds her fellow woman that the king is their father despite his deviant behaviour. She believes that their noise will wake Akeumbin from his sleep to come and attend to them. This is to say that words can change the situation not necessarily acts of revolt because bashing into the king's privacy is not only rude and disrespectful but also an abominable disregard for royalty. The traditional African is portrayed as a civilized personality not the uncouth barbarian that the colonial discourse presents illustrated by King Leopold II of Belgium in a speech in 1888 where he clearly avowed:

The mission which the agents of state have to accomplish in Congo is a noble one. They have to continue the development of civilisation in the centre of the equatorial Africa receiving their inspiration directly from Berlin and Brussels. Placed face to face with the primitive barbarism, grappling with sanguinary customs, which date back thousands of years, they are obliged to reduce this gradually. They must accustom the population to general laws of which the most salutary is assuredly of work (Qtd in Abanda: 30).

From every indication, this king is saying that Africa, represented here by the Congo, is a dark continent. The people to him are prehistoric barbarians who need to be cultured and schooled in matters concerning law and work. What he says points out a misleading claim classifying Africans as lazy lawless people. It is true that the men of Allehtendurih are lazy but the women are hard working and cultured implying that their husbands were not born lazy. The complexes they carry around should have caused their new found deviant comportment.

Furthermore, king Leopold explains that the European mission to this colony is intended "To open to civilisation the only part of the globe where Christianity has not penetrated and to pierce the darkness which envelops the entire population" (Qtd in Kimbrough 80). This of course is another erroneous statement because Africa had a religion before the coming of the Europeans. Indeed, Africans are known to be notoriously religious and of high moral standing. The African belief in gods, a supreme deity, and the presence of shrines, pouring of libation and incantations and the reliance on ancestral mediation, respect for elders, and hospitality among other practices were not taught by any white bigot. King Leopold is therefore a replica of colonial writers in his exalted language use and Africa a representation of the colonized.

The post-colonial text therefore emanates as a manifestation of local culture and history to debunk the grand narrative. Achebe in Things Fall Apart demonstrates that African people had dignity before the arrival of the colonial master. He goes on to demonstrate that colonialism ushered in a lot of chaos and disorder in an organised African society represented by the Igbo people of Nigeria. In Achebe's "The Role of the Writer in a New Nation: African writers on African Writing" he reiterates this assertion saying:

African people did not hear of culture for the first time from Europeans; that their societies [...] had a philosophy of great depth of value and beauty, that they had poetry and above all, they had dignity. It is this dignity that many African people all but lost during the colonial period and it is that they must now regain [...] The writer's duty is to help them regain it [...] In Africa he cannot perform this task unless he has a proper sense of history (8).

As the two women leaders of Allehtendurih speak, they notice that the princes are screaming in anguish too. They are squatting in a shade under the grove. These female leaders inform an inquisitive princess that the crow visible in the palace courtyard is just a tip of the iceberg for they are only leaders of women's meetings and "njangi" groups. Mafua emphasizes and promises that all the women of Allehtendurih will flood the palace courtyard if no one listens to their grievances. This will therefore look like the historical March of the women to Versailles in France to revolt against famine characterized by scarcity of bread, untold suffering and oppression. The case of Allehtendurih is a similar revolution, if not a more violent one but well organised. 
The women further complain that their children and they have suffered enough. They have been pushed to the wall and are now ready to bounce back as their leaders attest:

Mafua: Our children did not sleep in the night. They turned in their beds, cried, vomited and purged. And we have come to complain to the king.

M'meka: Our children are dying and the king and our husbands are silent. The king and our husbands! Men, we thought we were safe under their protection, men who should be ready at all times to unsheathe their machetes to fight when danger shows its ugly face [...]

Mafua: Men who should show us the right way when our fates are twisted and we don't know which way to take.

M'meka: But our men [...] Gods of our ancestors! Our men are absent. We only see them when they shout at us to serve them food or when at night they force our limbs apart and tear us into pieces. Even last night when our children were choking and dying, our men still shamelessly hung to our loin cloths pulling us [...] (57)

These two women highlight many roles that men have failed to perform as protectors of families. The king too has failed to play his role as guide and protector of the clan. Repetition of "the king and our husbands" by M'meka is used to emphasize the fact that the men have failed, so the women have to take over their duties. This is a feminist twist for the contemporary woman does not have to depend solely on her man. She should rather be emancipated to take over some traditional male roles as the women are doing in this play. They also speak out against violation when M'meka euphemistically says, “.... at night they force our limps apart and tear us into pieces”. The women know that the sexual act is supposed to be a mutual agreement between partners but their men are brutal and not romantic. In spite of this, the powerful women not only care for their selfish husbands who exploit them both sexually and materially, but are also especially concerned about their children's well-being. This role is not inferior to any male role. Nkengasong can therefore be read as a feminist because he projects female participation in contemporary society. The men must therefore treat their wives like equals not subordinates or second class citizens as the case may be in some traditional patriarchal societies.

Furthermore, the women in this play are crusaders of dialogue and change. This is essential in their community. The women's revolutionary words and actions stimulate the men especially the princes to break the ice. The princes therefore courageously join the women to articulate various changes and difficulties witnessed in their domains of control. Eseih, whose dominion is the earth, complains that the forest has disappeared thus the game have abandoned his dominion. Ntse, whose dominion is water, complains that streams, rivers and lakes to name a few, have become muddy and dirty thus, drinking water from these sources causes many diseases. He says this dryness came about because the trees at the catchments have all been felled. M'mok, the prince of fire, complains that he is about to destroy the world with fire because there has been too much burning. Lastly, Lebu the prince of the air protests that the air is heavy and toxic because of smoke and pungent smells. The women's march to the palace provoked the unveiling of many contemporary global issues such as climate change or global warming caused by the king's loyalty to western forest exploiters and burning by villagers. Ironically, the men were quiet about this precarious situation. They are powerless in the face of the women who took a bold step to confront the 'almighty' king. The author can be seen decrying wicked practices by egoistic modern men who care less about the well-being of others. Modern man is so selfcentred that he can fell trees, pollute the waters with industrial wastes, burn bushes and hunt even protected species such as elephants, chimpanzees and rhinoceros to enrich himself at the detriment of the human race. This practice is particularly unfair to future generations.

King Akeumbin is the epitome of this modern time insensitivity. As the head, he fails to seek solutions to the problem of famine and its ripple effects in his kingdom. He further refuses to collaborate with Alabi the priest, who proposes solutions to their predicament. Alabi's suggestion that sacrifices should be offered to appease the gods of the land, as prescribed by the traditional African religion, is rejected by the king for a selfish reason. The king claims that the priest is having a love affair with his beloved wife, Afingong. It should be noted that in this culture, this is considered an abominable crime punishable by inserting a broomstick in the culprit's sexual organ. The act, albeit seemingly cruel, is a powerful deterrent to potential criminals. African people therefore had a justice system before the infiltration of the Europeans. Anyway, customarily, his squabble with Alabi should not take precedence over the people's suffering. Thus the role of contemporary African Kings is questioned by the writer. Are they rulers for their own sake or for the subjects? This is the rhetorical question that is seemingly begging for an answer from the reader. The confusion, quest for power and desperation for material things has led not only Akeumbin but also many recent Fons and chiefs in real life situations to shamelessly practice overt partisan politics. They have almost thrown away values that made their ancestors fathers of all. These crowned heads have also done mean things for money, gifts or cheap popularity. The writer certainly castigates such comportment in this play thereby upholding African norms and religion which are not inferior to what exist in the west as brainwashed minds think. 
Besides, M'meka reiterates the King's egocentric and irrational nature when she posits that: "His heart is always bitter like the bile of the porcupine when it concerns Afingong. He prizes her more than all the women of Allehtendurih, their mothers and their mothers' mothers put together" (60). This combination of a simile and exaggeration x-rays Akeumbin's flaws. He like any other self-seeking human being is so pre-occupied with his sexual gratification, which his fiftieth and last wife provides, rather than taking care of the clan that the ancestors have placed under his custody. This of course is not good for the leader that he is supposed to be. He should have spent more time solving the serious problems that his village is facing. Unfortunately, the powerless king cares more about his beloved wife. The woman is actually more powerful in the African setting, contrary to western perception, as elucidated by the female characters in this play.

The king constantly quarrels with Alabi, who considers him the root cause of the problems of Allehtendurih, as seen in this conversation:

Lebu: [...] Alabi accuses the king of causing general suffering. He says the king has auctioned the forests of Allehtundurih to strangers, in exchange for a gun.

Ntse: $\quad$ The King and the Priest are like pork and fire.

Mafua: Who is roasting who?

Ntse: Sometimes the King roasts the Priest. At another time, the Priest roasts the King.

Esieh: And the King is bent on persecuting Alabi.

Mafua: (screaming) Wu eh eh eh eh! What shall the children of Allehtendurih tell their ancestors? (61)

In this conversation, Lebu points out a neo-colonial issue. The former colonial masters are still very much present on African soil. They pass through traditional and political leaders to exploit African resources just like they did during slave trade and colonial times. It is common knowledge that guns are mostly manufactured in the west. The western people are seen in Africa's forests through logging companies, which cut down trees with impunity. Unfortunately, many of these foreign companies make little or no efforts to replant, hence the complaint about deforestation and its adverse effects. The king in turn receives a gun, a triviality, in exchange for the trees cut. He is replicating what his predecessors did when they received alcohol, combs, guns and mirrors among other insignificant items from the white man in exchange for healthy young men and women during the dreaded slave trade era. Those who try to reproach the king like Alabi will definitely become his antagonists. The author here castigates repeated slavish acts perpetuated by powerless African kings and political leaders through the above conversation.

Furthermore, the author recommends a revolution, a redefinition of self through this verbal protest. African male leaders should revisit the values that prevailed before just like the powerful women are doing in this play. One of their leaders, Mafua laments the lost values and wonders what the people will tell their ancestors, who put these values in place, when they join them later on. She is highlighting the African belief system, which is life after death. Africans believe that they will meet their ancestors after death and account for their lives on earth. So to these people, life does not end at death. The said ancestors represent the saints in Christianity. Therefore, any claim by the west that religion is a western creation that had to be taught to Africans is castigated through this character. Africans had moral values and believed in God almighty before the coming of the Europeans with their Christian religion. In short, Africans had a history and culture, which is equal to western civilization from inception. Civilization has indeed become such a global phenomenon and no longer exists separately. Kwame Anthony Appiah, talking about culture, observes that:

The circulation of cultures in our post-modern moment makes it inevitable that we are all already contaminated by each other, that there is no longer a fully autochthonous etch-African culture awaiting salvage by our artists, just as there is; of course, no American culture without African roots ( qtd in Booker 3).

The conversation between the female leaders and the princes continues in the form of poetic rhetorical questions. This discussion serves as a reminder to everyone who wishes to know what obtains in their society.

Eseih: Does the squirrel no longer live in the tree?

Ntse: Does the crab no longer parade the bottom of the stream?

Lebu: Does [...], (prolonged sneeze), does the cloud no longer settle on the shoulder of the mountain?

Mafua: Shall we stand on the hill top like the cricket and call death to come and take us?

Ntse: Does the thunder no longer announce the coming of the rain?

Mafua: Does the she-goat no longer breast-feed the kid? even if the hen has no breast, shall it no longer feed the chick with the worms of the Earth? [...] (61)

All what is highlighted in the quotation happens in normal circumstances. If these princes and Mafua question the obvious, it is an indication that things are no longer the same. They are therefore using words to subtly ask for a revolution so that there should be no reversal of roles or values replaced by vices. A positive change and improvement on existing values would have been a welcome relief but this is not the case. 
The people are not living up to their responsibilities as illustrated by the king and the men of Allehtendurih. The women have consequently taken over the challenges in a culture where women are sometimes regarded as second class citizens. Conversely, these women know their rights and do not want to keep depending on the male folk because they are a disappointment to the clan. Thus, the women want to prepare a brighter future for their children. Failure to do this will result to curses from their progeny even when they must have left the scene. This idea is aptly brought out by Mafua in these words:

Where shall we hide our faces in the Earth, when our children, our children's children shall come hurrying to the ancestral shrine, crying of hunger and pain, hitting our skulls and cursing:" Mothers, wicked mothers! Why did you deliver us to the bad side of life? Why did you deliver us to a naked Earth?" Fuandem, a terrible thing has happened to Allehtendurih that mouths cannot speak! (62)

The women are so worried. They regard the fate of their village as alarming and abominable. On the contrary the men are not bordered. They spend their time drinking. When they manage to come back home, they ask for food and wish to have sexual gratification at night. Of course, the emancipated women of a typical African village of Allehtendurih do not succumb to this power display. They decided to go on a sex strike, starving their men for a while for their passive behavior. This class of men today blames it on women emancipation claiming that since women have advocated gender equality; they should live up to expectation. It is rather a distraction on the part of these chauvinists who need to reassert themselves.

The women's persistence finally brings the king out to meet and listen to them. Despite the flattery and euphemistic words used by the princes, M'meka and Mafua to prepare the king's ears for their bitter complaints, the latter retorts with unkind sarcasms thus:

(sternly) go and till the soil, you lazy women of Allehtendurih. Your husbands are kind else they should return you to your fathers and ask the refund of the bride price. I have, with my foreign friends, cut down the forests, and open the land so that you work freely on the soil. And you come here complaining of hunger and disease instead of working? Go and till the soil before I tell your husbands what to do with you (63-64).

The king offensively accuses the struggling women of laziness. He conversely sees nothing wrong with their slothful husbands, reason why nearly all feminist criticisms started from one fundamental perception, recognition of the patriarchal structure of the society. This structure mirrors a society organized on terms dictated by men and obviously to the advantage of men. Virginia Woolf's A Room of One's Own (1928) and Simone de Beauvoir's The Second Sex (1949) vividly elucidate this patriarchal structure. The women are once more oppressed for they can be bought and sold, used and refunded to their parents as the king implies. This is what the feminist decries vehemently. M'meka and Mafua portray themselves as feminists for they do not cowardly run away following the king's irrational claims and orders. On the contrary, these powerful women rather defy Akeumbin's orders and persist on their ideologies in a polite but firm tone:

M'meka: Nyatemeh! We cannot move. Our feet are fastened to the root of this palace [...], to the root of the Tree of Life that bleeds and we feel the pains.

Mafua: We till the soil everyday from when the partridge sings praises to the morning to when the owl scares us at dusk with evil songs. But the soil mocks at us, and the crops grow sickly then wither. Akeumbin: Stand there then, and keep croaking like pregnant toads[...](64)

The king continues to mock the women whom he likens to croaking pregnant toads. This means that all their endeavors to bring the king to reason have failed. The king who thinks he is all powerful ignores them by directing his attention to the princes. He commands them to punish Alabi for sleeping with his wife as the laws of the land prescribe. Akeumbin addresses the princes thus:

You princes of the Earth, I summoned you here this morning to Lefem to execute the punishment of adultery on Alabi at the shrine of our ancestors. As tradition demands, whoever sleeps with the king's wife shall face the persecution of the broomstick. And this shall be done in the presence of Afingong my youngest wife whom he has destroyed with charms (64).

Akeumbin wants a punitive action to be taken on his suspected rival. The act though barbaric serves as a corrective measure on the culprit and is also meant to scare and deter prospective adulterers in this traditional setting. The king is therefore more interested in punishing a man who has not even been proven guilty. He is out to protect his interest for he does not punish his wife under the pretext that Alabi used charms on her. Nonetheless, the king's action exonerates the woman unlike the adulterous woman in the Bible. 
This is a revolutionary act by Akeumbin and the playwright by extension. It is a laudable change because women are always victimized. It also exposes the flaws and biases in legal systems in Africa and the west. The law should normally be applied likewise to criminals who commit the same crimes no matter their sex.

Mafua and M'meka vehemently condemn the king's proposed punishment on Alabi. Akeumbin says he has consulted the ancestors and according to tradition, a broomstick should be inserted and broken in Alabi's "maker-of-children" (idem). After this, he should be taken to the furthest forest and banished for life. The two female leaders vehemently protest against this proposed abomination and caution the king against bringing more curses on their land through this dreadful action. This barbaric form of punishment could also be substituted. The women thus appeal to the king's conscience because he has become unbelievably irrational and insensitive. Women are therefore articulating and fighting against injustices that not only concern them but their male counterparts and the society as a whole. The woman is consequently portrayed as the mother of humanity not a powerless subordinate to man.

One moral lesson to learn from this play is that a leader has to listen to his subjects if he must succeed in his difficult task. These subjects may be men, women or even opponents or rivals. A listening ear always takes home something. This is what Akeumbin has so far failed to do. Alabi however continues to bring Akeumbin to his right senses just like the female leaders are despite his resistance:

Alabi: Akeumbin, is this Earth the Earth of Allehtendurih which many seasons ago was the song of joyful robust men, women and children?

Akeumbin: Answer your charge first. Do not become the woman who goes to deliver but first gives birth to her womb. Alabi: Akeumbin, is this the Earth, our ancestral Earth, which when we were young, pulsed with life? (67)

Alabi tries to touch every aspect of life in Alletundurih village which is now in jeopardy but Akeumbin's only insistence is on the former's punishment. He pushes Trohndi to action but this is not forth coming probably because Alabi's words are pregnant with meaning. He invokes memories of the affluence that had existed and was enjoyed by every villager prior to this demise. People were joyful, the farms were productive, the forests were bustling with game, the streams, rivers, lakes were jubilant with fish and other aquatic life. In short, Allehtendurih was "the wealth of nations" but the reverse is true in Akeumbin's reign. Alabi, the eloquent speaker continues by presenting the ugly picture of their village in recent times. This is also a warning to the king not to invite more trouble on their land by committing the abominable act he is persistently ordering Trohndi to carry out on his genital organ. This is how the said village looks like presently through Alabi's poetic eyes:

The fields of Allehtendurih wither, the mountains stand like a sore in the eye of the sun, the streams dry up, the air chokes and the strangers are there digging up things only gods alone know and carting them away to their country, cutting down trees and destroying our totems as if they have heard the world was coming to an end so soon. And the children of Allehtendurih are sick they are dying, dying. Akeumbin, I cannot feel the warmth of Allehtendurih any more. I cannot feel the warmth of this Earth anymore (68).

Alabi seems to be the only powerful sane man left in this village to rescue the male folk from complete brainwashing. $\mathrm{He}$ is a traditional African priest who is observant and brave to tell the king the bitter truth. He foresees and forecasts the imminent danger even without western knowledge of geography or meteorology hence, demystifying the Eurocentric claim that their education is supreme. Traditional Africans are intelligent and do not depend on western education for wisdom or bravery. The frightening picture he presents serves as a warning to the people of Allehtendurih and Africa as a whole. If nothing is done about the ecosystem that is gradually but steadily being destroyed by foreigners in particular, the people will suffer harsh weather conditions. Western countries usually have floods, tornadoes, hurricanes, earthquakes and droughts. Africans risks having these same weather conditions in future. Africans must therefore preserve the natural wealth provided by God or face the music. This issue of the devastation of the ecosystem and the need to do everything possible to conserve what is left is also addressed by the church represented by Pope Francis in his Insiclica titled "Laudato Si". The need for a change of attitude is certainly of utmost importance.

Akeumbin calls his chief executioner, Trohndi, a traitor because he has so far refused to insert the broomstick into Alabi's reproductive organ. Consequently, some revolutionary words are exchanged between the king and priest. The priest, Alabi, actually retorts on behalf of Trohndi who is the object of the king's attack this time around:

Alabi: Akeumbin, you are the traitor to the children of Allehtendurih. You have sold their land because of greed and wickedness.

Akeumbin: Slave, do you call me "traitor"? Do you know on which Earth you stand?

Alabi: On the Earth of our ancestors and not that of Akeumbin (70). 
The priest seems disrespectful but he is left with nothing but the truth no matter how bitter it is. He is brave, fearless and teaches the reader to stick to the truth despite the cost. The truth, which is an African value, eventually sets Alabi free. The king is nervous and domineering as construed from his use of insults on the executioner and priest. He dictates and arrogates powers for wrong purposes, reason why Trohndi does not obey his order to punish the innocent priest. Africans surely had credible canons such as belief, justice and democratic systems from inception so their history is not at its threshold as classified by Eurocentric minds.

Everyone abandons the king at this moment because he is so arrogant. The executioner and the princes silently refuse to obey his orders and this enrages the king. Akeumbin's words and stage directions below are elucidations:

Bring my gun and stop sneezing. Do you keep bees in your nostrils? (Silence.) Is no one moving? (Rises and moves about angrily) Hoii! Will no one move? Will no one answer? (Silence.) Answer me or I shall wrench off all your heads. (Silence.) Where is Nkem M'mok?...(Pause) Nkem Esieh! Nkem Lebu! Nkem Nntse! (Silence.) Has the wizard struck everyone here dumb?... I say bring my gun else Amob will strike all of you to death. (Pause then louder.) My g-u-n! (Rushes to Esieh and tries to unsheathe his machete. Esieh holds it firm to his waist. Akeumbin stands shocked and stares about, bewildered.) (70-71)

All what the king says here reveals revolutionary actions on his part and that of his cohorts. He moves about angrily and the reader can visualize an enraged face, full of anger, ready to kill. The cronies conversely remain still and silent. Eseih holds his machete firm to his waist thereby restraining the king from taking it to kill Alabi or anyone else. The stage directions here also unravel acts of resistance and protest. This indicates that no king or political leader should imagine himself above the law or greater than his people. This has happened in real life situations where one time purportedly great leaders are dragged to court to answer charges against them. Some of them are even killed like little flies. Take the case of Nicolas Sarkozi of France, Hosni Mubarak of Eygpt, Sadam Huissen of Iraq and Mahamat Ghadhafi of Libya among others. These leaders might have been bewildered like king Akeumbin at the fate that befell them. World leaders who think themselves indispensible and untouchable have much to learn from these fallen presidents. In line with this, Chinua Achebe makes a prophetic statement in No Longer at Ease "that no man however great is greater than his people, that no one ever won judgment against his clan" (19). King Akeumbin and the fallen leaders earlier mentioned actually experience this. We also learn that democracy is not a western invention and prescription to Africa. Dictators such as Akeubin have never succeeded in mother Africa no matter how long they cling to power. Their end is usually disastrous though many current African dictators have failed to learn from history because of neocolonialism.

Furthermore, in spite of the fact that the cohorts are not executing the king's orders, he stubbornly continues to claim to be the only one in command thereby making himself a ridiculous dictator. In the following dialogue Akeumbin displays a deceptive superiority complex over his subjects.

Akeumbin: There is no question of listening to queer old idle women.(Grumbling of women)

Afingong: But they want you to appease the ancestors, my husband.

Akeumbin: No!

Afingong: That is what they say.

Akeumbin:(Rising vehemently.) Who said it? ... Shall anyone tell me, Akeumbin, what I should or should not do? Let the Earth of Allehtendurih crumble into some deep darkness and leave me and my bride alone. (The women hail a cry of denunciation.) Stop croaking there, you pregnant toads. (Another cry of denuncitation [...] ) (72-73)

The women revolt by grumbling and overtly denouncing the king. He orders his wife to pinpoint whoever asked him to appease their forebears so they could be punished but Afingong remains quiet. This action is a revolt against the king. He becomes shamefully powerless before his subjects. No one actually obeys his orders because he is a ruthless despot. This is true to life because subjects have dethroned or killed their callous kings. It happened in Babanki, North West Region of Cameroon some years back.

This revolt by the people of Allehtendurih drives Akeumbin to further quest for his identity. He continuously asks for his gun to kill anyone who challenges his authority but nobody obeys. The confused king Akeumbin therefore continues to seek his exact identity as seen below:

Akeumbin: [...] Are not these faces I see around me? (Loud) My g-u-n! (Pause) Am I of any substance? Do I have flesh? Bring my gun! (Silence.) No one is moving still? Do they not hear the roar of the lion? Or am I deaf and dumb and could only hear my own voice? (Louder) My g-u-n!

Alabi: You have destroyed the jungle, Akeumbin. And so there can be no lions.

Akeumbin: What? Alabi, do you still live? I shall go for the gun myself. (Rises about to exit? Turns instead and grabs Alabi on his neck. There is a brief scuffle.) Adulterer? I will murder you with my hands (73). 
Afingong, who cannot stand this scuffle, rises and pulls Akeumbin to his royal stool as the stage directions indicate on the same page. These are revolutionary acts. Afingong further acts in a violent manner when she cuts off her necklaces, throws them to the ground and crosses over to join the women. She recognizes the fact that she too will be a mother and cannot continue to live in luxury while her folks are miserable. She therefore changes, becomes reasonable and chooses to empty herself of royal deception to commune with her kith and kin. Here with revolutionary acts and words by Afingong:

(Rises and pulls Akeumbin to his royal stool.) Listen, Your Majesty I feel a sharp pain in my womb. If for my sake, you shall leave my mothers and their children in pain and agony Then, I shall cut these necklaces that sever me from my umbilical cord, and join my mothers in their misery until you listen to their plea. I too shall have children, Your Majesty. (Cuts off the necklaces, throws them on the ground and crosses over to join the women.)(73)

All these words and revolutionary actions by Afingong culminate in a revolution in Akeumbin. The woman's powerful words and actions constraint the king to change hence, the feminine gender should no longer be regarded as weak or powerless. Women have always been naturally powerful in some domains from genesis and African men know this. It should be noted that the wise counseling by the princes, who remain dedicated to royalty, also contribute to the change that the king goes through. This teaches us that a leader must not be obeyed sheepishly. He can also be wrong thus must be corrected. Unfortunately, the scenario around African leaders, both traditional and political, is so deceptive. Close aides to these leaders either stay quiet or misinform the latter in order to stay in power or in the name of loyalty. These so-called close collaborators do not have the people's plight at heart. They need to return to African values of truth, honesty, bravery and selflessness as demonstrated by the princes, Afingong, Alabi and the women among others. It is so disgusting and frustrating witnessing praise singing and support to a leader where they should be given frank corrections and pieces of advice aimed at improving the livelihood of the masses. This deception only plunges the society into chaos such as that which we are living today in most African societies including Cameroon.

Akeumbin, who seems so adamant, finally succumbs to the pleas of the people. He has learnt a lesson that he is not greater than anyone in the village despite the fact that he is a king. In fact, greatness can only be accomplished when he listens and collaborates with his subjects. He learns this lesson the hard way for the princes, executioners, the women including his beloved wife, Afingong deserts him to join her women folk in the fight. He cannot believe this and so doubts and quests for his identity when he asks questions in the dialogue that ensues:

Akeumbin: [...] Have i been bewitched? Is this Akeumbin? Is this the voice that cried "Hoii!" and princes trembled? Nkem Ntse! Nkem Lebu[...] See. They stare at me as though I was a shadow.

Eseih: Nyatemeh, you are not a shadow.

Akeumbin: Then who am I?

Eseih: You are our king, the custodian of our lives.

Akeumbin: I am a shadow, you cannot deceive me. There is no substance in me if the roar of the lion will not make a rat panic. There is no substance in me. (Falls first on knees, then lies prostrate on the earth, while the women and men watch him [...] ) (74)

The king's words and stage directions mirror a changed man. He has now come to terms with reality. He had deceived himself for years that he is the Alpha and Omega. Now that the truth about life has been unfolded right in his face, he now sees the nothingness of man and the need to return to a communal life style, which is an African endangered value. The adage which says no man is an island holds true in this instance and so the king remains great only as long as he cares about the welfare of his people. Acts of tyranny, wickedness and greed by the ruler can lead very loyal citizens to defiant revolts which might be verbal or displayed in action. No one could have dreamt that such loyal rural people would react the way they do against their king in this play. Contemporary African societies, especially ours, have much to be reminded of or learn from this wonderful play by Nkengasong.

The king however pleasantly becomes reasonable, repentant, and peaceful. He eventually performs the ritual that his people demanded. Akeumbin's repentance is depicted in these words: "Gods of my ancestors, forgive me for my pride. Let this oil soften your hearts and make me rule Allehtendurih with the wisdom of our ancestors." (There is a sound of the rushing wind.Sound fades. Ancestral voice is heard from withal.) (77) This happens after the sacrifice of salt, oil and 'njieh' is sprinkled round the skulls. The ancestor therefore responds almost immediately after the cleansing ritual is performed by Akeumbin. It goes without saying that Africans had a pragmatic belief system before the coming of the Europeans. The abovementioned Ancestral Voice blames everyone for contributing to the destruction of the Earth. Akeumbin is blamed for his pride and greed. He accepts, apologizes and proposes solutions to the calamity. The women are blamed for burning the bushes for farming. They are remorseful for their ignorance. So too are the princes who are accused of hunting all the game which form part of the eco-system. The King thus addresses his subjects to this effect: 
Children of Allehtendurih! I have put you in agony with my pride, my greed and foolishness. If a snake bites you, flee at the sight of a millipede. Let us be wise now. Our elders say that you do not feed a goat only on the day you want to take it to the market. The Gods of the Earth have spoken a lot and we don't yet understand[...] Go now, every one[...] With your children [...] And bring a seed, a young plant or a stem that can be cut and planted[...] And we shall plant them all over the barren lands of Allehtendurih. Go now (79-80).

The king's address motivates the people to get seeds and seedlings for planting. They sing songs as they go along, promising to take good care of the earth. This is a revolution in reality. The play ends on a positive note. There is hope that the situation in Allehtendurih will get better because the subjects are willing to collaborate with their repentant ruler. African leaders in particular should learn from Akeumbin that there is great honour in humility. A ruler can always renounce his pride and selfish tendencies for justice and peace to reign. In fact, this will make him more powerful and famous. Any leader who refuses to act reasonably like our king in this play is not fit to be one. He/she should be dethroned or replaced.

\section{Conclusion}

The play, Ancestral Earth by John Nkemngong Nkengasong, exposes gender biases where the male represses the female. Male characters generally epitomize a patriarchal society by assuming and claiming authority over the female. The male gender tries to exercise power by exploiting the female gender materially and sexually. The women of Allehtendurih are exploited by their husbands and the king finds nothing wrong with it. Instead, he insults them and threatens them in solidarity with his male folk. However, this politics of power or male hegemony is not accepted by the female gender in this play. However, this politics of power or male hegemony is not accepted by the female gender in this play. The organized women of Allehtendurih group themselves under the leadership of influential leaders, Mafua and M'meka and fight for their rights. The protest in word and action and finally emerge victorious. The injustices cause the female gender to resist confirming the fact that when injustice becomes law then resistance becomes a duty. The resistances put forth by these women, especially the king's fiftieth wife, tame both their husbands and the king. They finally agree with the women after a tough battle of words and actions such as sex starving. King Akeumbin performs the long awaited sacrifice to appease the gods as requested. He equally orders the planting of tress and other crops to boost the deteriorating eco-system and farm products for subsistence. The female gender triumphs after all. After reading the characters from what they say, do and what others say about them, we can therefore, finally conclude that the female gender emerges more powerful in this play rendering the men powerless despite their superiority claims. Nonetheless, there is one sane man in the person of the traditional priest; Alabi, who is a symbol of hope. The female characters represent wisdom, respect, resilience, maturity, hard work and what have you. They are sure signs of hope and continuity for the community. The epitomize morality and good leadership. Therefore, women should never underestimate themselves for they are quite influential and worthy examples. The playwright can be read as a feminist for he empowers the female gender and liberates them from chauvinistic male hegemony. Women are conquerors, indeed.

\section{Bibliography}

\section{Primary Source}

NKENGASONG, John, Nkemngong, Black Caps and Red Feathers and Ancestral Earth, Bamenda, Langaa Research \& Publishing Common Initiative Group, 2010.

\section{Secondary Sources}

NKENGASONG, John, Nkemngong, The Call of Blood, Bamenda, Langaa RPCIG, 2010.

ACHEBE, Chinua, Things Fall Apart, London, Heinemann, 1958.

AIDOO, Ama Ata, The Dilemma of a Ghost, New York, Longman Publishing Group, 1951.

ARNDT, Susan. The Dynamics of African Feminism: Defining and classifying African Feminist Literature, Asmara, African World Press Inc, 2002.

ASCROFT, Bill et al., The Post-Colonial Studies Reader, London, Routledge, 1995.

ASCROFT, Bill et al., The Empire Writes Back: Theory and Practice in Post-Colonial Literatures, New York; Methuen, 1989.

BUTAKE, Bole, Betrothal without Libation, Yaoundé, Editions CLE, 2005.

BRANNIGAN, John, New Historicism and Cultural Materialism, New York, Methuen,1998. 
CHINWENZU, Onwuchukwu, Jemie and Ikechukwu, Towards the Decolonisation of African Literature, Vol 1, Enugu, Fourth Dimension Publisher, 1980.

FRIEDAN, Betty, The Feminine Mystique’ Dell Publishing Co, inc. 750 Third Avenue, New York, 1963.

GORDON, Vivian, Black Women, Feminism, and Black Liberation: Which Way? Chicago, Third World Press, 1989.

GUERIN, L. Wilfred et al, A Handbook of Critical Approaches to Literature, New York, OUP, 1972.

GUERIN, Wilfred L. et al, A Handbook of Critical Approaches to Literature 3rd Ed., New York, Oxford University Press, 1992.

HUMM, Maggie, The Dictionary of Feminist Theory, Worcester, Billing and Sons Ltd, 1989, p.74.

KILLAM, G. D. Ed, African Writers on African Writing, London. Heineman, 1973.

LONGMAN, Contemporary Dictionary of English. England: Pearson Education Ltd, 2003.

SAID, Edward, W. “Orientalism”, The Post Colonial Studies: Eds. Bill Ashcroft et al., London, Routledge, 1995. 8991.

LYRE, John. "Post-colonial Literature". 2001. 16 Dec. 2007. http://www.Brochu:ca/English/coursed:4f 70/post. Col. $\mathrm{Html}$ 